NASA/CR-2005-213582

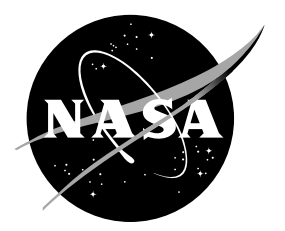

\title{
Thermo-Physical Properties of Intermediate Temperature Heat Pipe Fluids
}

Angirasa Devarakonda

Sest, Inc., Middleburg Heights, Ohio

William G. Anderson

Advanced Cooling Technologies, Lancaster, Pennsylvania 
Since its founding, NASA has been dedicated to the advancement of aeronautics and space science. The NASA Scientific and Technical Information (STI) Program Office plays a key part in helping NASA maintain this important role.

The NASA STI Program Office is operated by Langley Research Center, the Lead Center for NASA's scientific and technical information. The NASA STI Program Office provides access to the NASA STI Database, the largest collection of aeronautical and space science STI in the world. The Program Office is also NASA's institutional mechanism for disseminating the results of its research and development activities. These results are published by NASA in the NASA STI Report Series, which includes the following report types:

- TECHNICAL PUBLICATION. Reports of completed research or a major significant phase of research that present the results of NASA programs and include extensive data or theoretical analysis. Includes compilations of significant scientific and technical data and information deemed to be of continuing reference value. NASA's counterpart of peerreviewed formal professional papers but has less stringent limitations on manuscript length and extent of graphic presentations.

- TECHNICAL MEMORANDUM. Scientific and technical findings that are preliminary or of specialized interest, e.g., quick release reports, working papers, and bibliographies that contain minimal annotation. Does not contain extensive analysis.

- CONTRACTOR REPORT. Scientific and technical findings by NASA-sponsored contractors and grantees.
- CONFERENCE PUBLICATION. Collected papers from scientific and technical conferences, symposia, seminars, or other meetings sponsored or cosponsored by NASA.

- SPECIAL PUBLICATION. Scientific, technical, or historical information from NASA programs, projects, and missions, often concerned with subjects having substantial public interest.

- TECHNICAL TRANSLATION. Englishlanguage translations of foreign scientific and technical material pertinent to NASA's mission.

Specialized services that complement the STI Program Office's diverse offerings include creating custom thesauri, building customized databases, organizing and publishing research results ... even providing videos.

For more information about the NASA STI Program Office, see the following:

- Access the NASA STI Program Home Page at http://www.sti.nasa.gov

- E-mail your question via the Internet to help@sti.nasa.gov

- Fax your question to the NASA Access Help Desk at 301-621-0134

- Telephone the NASA Access Help Desk at 301-621-0390

- Write to:

NASA Access Help Desk

NASA Center for AeroSpace Information 7121 Standard Drive

Hanover, MD 21076 
NASA/CR-2005-213582

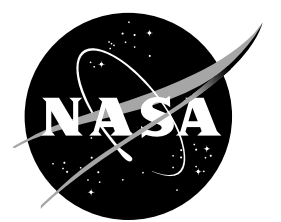

\section{Thermo-Physical Properties of Intermediate Temperature Heat Pipe Fluids}

Angirasa Devarakonda

Sest, Inc., Middleburg Heights, Ohio

William G. Anderson

Advanced Cooling Technologies, Lancaster, Pennsylvania

Prepared for the

Space Technology and Applications International Forum (STAIF-2005)

sponsored by the University of New Mexico's Institute for Space and Nuclear Power Studies (UNM-ISNPS)

Albuquerque, New Mexico, February 13-17, 2005

Prepared under Contract NAS3-03064

National Aeronautics and

Space Administration

Glenn Research Center 


\section{Acknowledgments}

This work was performed under NASA's Prometheus through Contract NAS3-03064.

Available from

NASA Center for Aerospace Information 7121 Standard Drive

Hanover, MD 21076
National Technical Information Service 5285 Port Royal Road Springfield, VA 22100

Available electronically at http:/ /gltrs.grc.nasa.gov 


\title{
Thermo-Physical Properties of Intermediate Temperature Heat Pipe Fluids
}

\author{
Angirasa Devarakonda \\ Sest, Inc. \\ Middleburg Heights, Ohio 44130 \\ William G. Anderson \\ Advanced Cooling Technologies \\ Lancaster, Pennsylvania 17601
}

\begin{abstract}
Heat pipes are among the most promising technologies for space radiator systems. The paper reports further evaluation of potential heat pipe fluids in the intermediate temperature range of 400 to $700 \mathrm{~K}$ in continuation of two recent reports. More thermo-physical property data are examined. Organic, inorganic and elemental substances are considered. The evaluation of surface tension and other fluid properties are examined. Halides are evaluated as potential heat pipe fluids. Reliable data are not available for all fluids and further database development is necessary. Many of the fluids considered are promising candidates as heat pipe fluids. Water is promising as a heat pipe fluid up to $500-550 \mathrm{~K}$. Life test data for thermo-chemical compatibility are almost non-existent.
\end{abstract}

\section{INTRODUCTION}

The National Aeronautics and Space Administration (NASA) is developing advanced space power conversion systems for deep space science missions. As a part of this effort, the necessary radiator technologies for rejecting large amount of waste heat into space are also being developed. In order to realize the twin objectives of higher power conversion efficiencies and smaller radiator size, the temperature range of $400-700 \mathrm{~K}$ for heat rejection is considered as an envelope.

Heat pipes are among the most promising heat transport and heat spreading devices for incorporating into space radiator systems. A heat pipe is a passive two-phase sealed device that transports large amount of heat with minimal temperature drop. Heat pipe technologies differ considerably depending on the operational temperature range. The thermo-physical properties of the heat pipe fluid and the thermo-chemical compatibility of the envelope and wick material with the fluid are the main scientific issues. The temperature range of 400-700 K is defined as Intermediate (Devarakonda and Olminsky, 2004). While heat pipe technologies have matured in other temperature ranges over the years, in the intermediate range they are less developed (Anderson et al., 2004). NASA Glenn Research Center is investigating intermediate temperature heat pipe technologies. As an aspect of this technology development drive, an evaluation of as many potential heat pipe fluids in this temperature range as possible was undertaken. This paper is a continuation of this evaluation effort following two other recent reports (Anderson et al., 2004; Devarakonda and Olminsky, 2004). More accurate thermodynamic and thermo-physical property data for some of the fluids discussed in the earlier reports have since been obtained and data for some other fluids have been gathered and analyzed for this report.

\section{INTERMEDIATE TEMPERATURE HEAT PIPE FLUIDS}

Devarakonda and Olminsky (2004) list the requisite properties of potential heat pipe fluids for intermediate temperature heat pipes. These may be summarized as 
- wet a metallic solid surface

- high latent heat of evaporation

- melting point below $\sim 400 \mathrm{~K}$

- critical point above $\sim 800 \mathrm{~K}$

- chemically stable in the above temperature range, i.e., no ionization and dissociation

- low liquid viscosity

- high surface tension

- non-toxic, non-carcinogenic

- non-volatile/low volatility

These requisites are only indicative for the entire intermediate temperature range, i.e. 400 to $700 \mathrm{~K}$. This range appears somewhat arbitrary. The rationale behind it is that below $400 \mathrm{~K}$, water heat pipe technology is wellestablished, and above $700 \mathrm{~K}$, alkali metal heat pipes work very well. Even if a fluid is potentially suitable for only a segment of this range, it is still considered for evaluation.

Two quantitative factors used in evaluating the suitability of a given fluid for heat pipe application are its vapor pressure and a merit number (also variously called the liquid transport factor or the figure of merit), M, defined as

$$
M=\frac{\rho_{\mathrm{L}} \cdot \sigma \cdot \lambda}{\mu_{\mathrm{L}}}
$$

The merit number is formed by grouping the desirable properties of the fluid in the numerator and the less desirable in the denominator. Hence, the larger the value of $\mathrm{M}$, the more suitable is the fluid for heat pipes. The importance of each of these properties individually and in combination in the evaluation of heat pipe fluids will be discussed. First a list of potential heat pipe fluids is chosen based on their melting and critical points. Stull (1947) presented vapor pressure data for an exhaustive list of elemental, organic and inorganic fluids.

The initial screening and evaluation of a heat pipe fluid is done with the vapor pressure and merit number data. If a fluid shows promise on this basis, then thermo-chemical compatibility studies with potential envelope and wick metals will be undertaken.

\section{SOME CANDIDATE FLUIDS AND PROPERTIES}

Available test data support water heat pipe's operational temperature up to $400 \mathrm{~K}$ (Devarakonda and Olminisky, 2004). The rule of thumb for maximum operational temperature for a fluid is about $100 \mathrm{~K}$ below its critical temperature. Hence water heat pipes are candidates for operational temperatures $\sim 550 \mathrm{~K}$ and somewhat above. Test data are needed for water heat pipes in the range 400 to above $550 \mathrm{~K}$. One important issue that needs to be addressed with water at these temperatures is its high vapor pressure. The vapor pressure of a heat pipe fluid at the operational temperature is an important factor. High vapor pressures require thick envelope walls as well as stronger braze/welds. Too low vapor pressure will result in large temperature gradients along the length of the heat pipe.

The list of potential heat pipe fluids for the desired operating temperature range is shown in Tables 1 and 2. Data are collected from various sources including CRC Handbook (1976), Janz (1988), Meyer et al. (1993), Ohse (1985), Perry and Green (1984), Reid, Prausnitz and Poling (1987), Stull (1947) and Smithells (1983). Water data are given as benchmark and as a potential heat pipe fluid up to $550 \mathrm{~K}$. Because of their wide ranging applications in commercial electronic cooling, water heat pipe technologies have been refined over the years. However, most of the life test data are at lower temperatures, which are not suitable for intermediate temperature radiators. Anderson and Stern (2005) report on some on-going life test data, which indicate that titanium and Monel K-500 are potential envelope and wick materials. Life test data at the intermediate temperatures for copper-water heat pipes are not available.

\section{Halides and Elemental Pure Substances}

A halide is a compound of the type MX, where M may be another element or organic compound, and X may be fluorine, chlorine, bromine, iodine, or astatine. Some of the halides are thought to have the desirable properties and 
characteristics of an intermediate temperature heat pipe fluid. In addition, elements like sulfur and iodine are also surveyed.

Unfortunately, the physical property data for many of the halides are incomplete. As shown in Table 2, many of the fluids do not have data for at least one of liquid density, liquid viscosity, or surface tension data. The known properties of one halide in a family may be used to estimate the properties for related halides, i.e., use the $\mathrm{AlCl}_{3}$ data to estimate $\mathrm{AlBr}_{3}$ and $\mathrm{AlI}_{3}$ properties. The approach taken below is to use the fluid property estimation methods discussed in Reid, Prausnitz, and Poling (1987). If a method is found that can calculate known properties in a family, then that method is used to estimate liquid viscosities in other families, based on the known data. In some cases, there are no data for any fluids in a particular halide family. These halides were not considered further, since there were no data (typically surface tension and/or liquid viscosity) for any member of the family:

- $\mathrm{BCl}_{3}, \mathrm{BBr}_{3}, \mathrm{BI}_{3}$

- $\mathrm{SiCl}_{4}, \mathrm{SiBr}_{4}, \mathrm{SiI}_{4}$

Possible halide fluids are then the halides of Al, $\mathrm{Bi}, \mathrm{Ga}, \mathrm{Sb}, \mathrm{Sn}$, and Ti.

\section{Surface Tension Estimation}

Reid, Prausnitz, and Poling (1987) suggest that surface tension can be estimated using a corresponding states equation, when the critical properties and normal boiling point are known. A parameter $\mathrm{Q}$ is first calculated as

$$
Q=0.1196\left(1+\frac{\frac{T_{\text {Boil }}}{T_{\text {Critical }}} \ln \left(P_{\text {Critical }}\right)}{1-\frac{T_{\text {Boil }}}{T_{\text {Critical }}}}\right)
$$

where $\mathrm{P}_{\text {Critical }}$ has units of bar and $\mathrm{T}_{\text {critical }}$, Kelvin. The surface tension is then calculated with

$$
\sigma=\mathrm{Q}\left(\frac{\mathrm{P}_{\text {Critical }}}{\text { Bar }}\right)^{\frac{2}{3}}\left(\frac{\mathrm{T}_{\text {Critical }}}{\mathrm{K}}\right)^{\frac{1}{3}}\left(1-\frac{\mathrm{K}}{\mathrm{T}_{\text {Critical }}}\right)^{\frac{11}{9}} 10^{-3} \frac{\mathrm{N}}{\mathrm{m}}
$$

This equation was used to estimate the iodine surface tension. Better agreement with known values of halide can be obtained by multiplying the above equation by $2 / 3$ as

$$
\sigma_{\text {Halide }}=\frac{2}{3} \sigma
$$

Experimental and estimated values of surface tension are shown in Fig. 1. The agreement between the two is excellent for the three fluids where both surface tension and critical properties are known.

\section{Vapor Pressure and Merit Number}

Anderson et al. (2004) discussed the evaluation of the organic fluids, aniline, naphthalene, toluene, hydrazine, and phenol. In general, the vapor pressures as well as the merit numbers of the organic fluids are lower than those of water at a given temperature. Organic molecules are heavy. Hence, an important issue that needs experimental verification is the chemical stability (i.e., whether or not they decompose) of the fluids at elevated temperatures subjected to radiation, and the continuous cycling of evaporation and condensation. For heat pipes suitable for space radiators, cesium is a good working fluid at temperatures above $\sim 700 \mathrm{~K}$ (Anderson, 2005). It has been used in both heat pipes and loop heat pipes (Anderson et al., 1995). Below $700 \mathrm{~K}$ the vapor pressure is low, vapor velocities are high, and the viscous and sonic limits control the heat pipe. Vapor pressure data for a number of fluids are plotted in Fig. 2 with water as the high end limit and Cesium as low end. The vapor pressures of all the substances considered 
fall within this range. Judging purely from the point of view of vapor pressure, any or all of these fluids are candidates for intermediate temperature heat pipes.

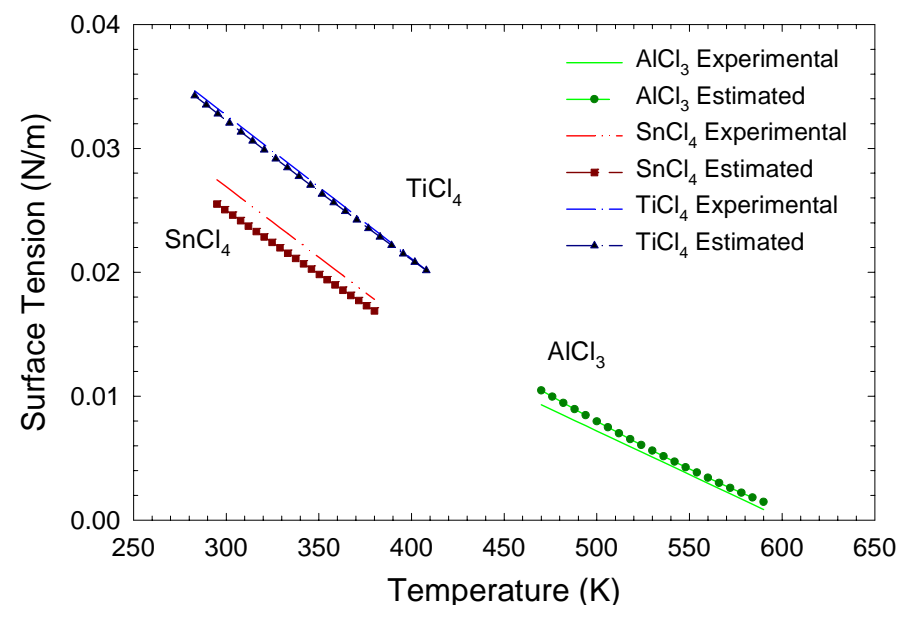

FIGURE 1. Surface Tension Calculated with the Corresponding State Equation Shows Good Agreement with the Experimental Value.

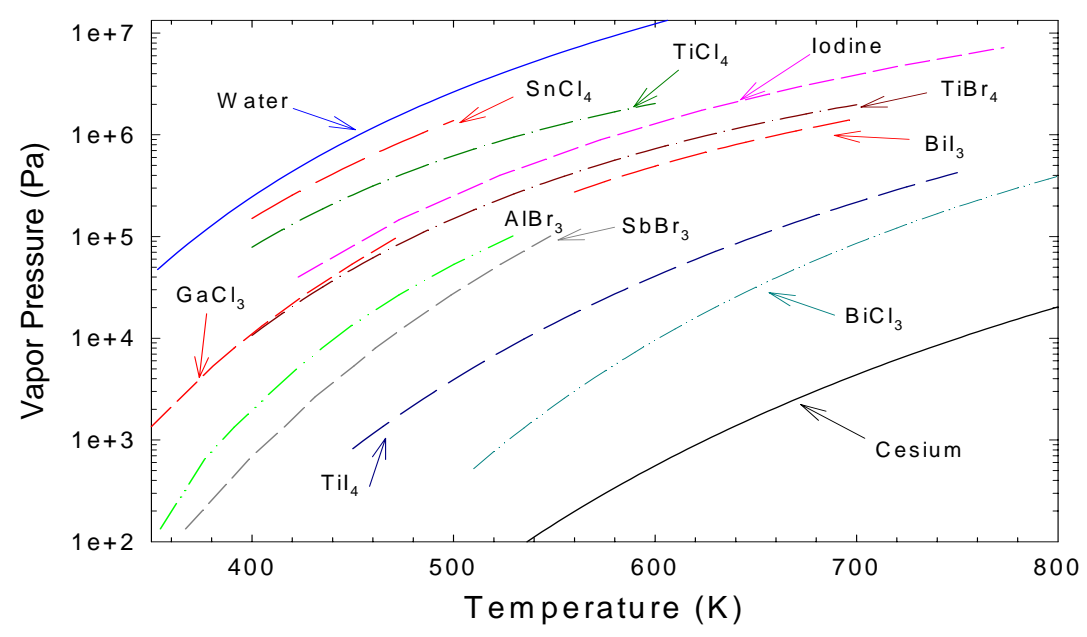

FIGURE 2. Vapor Pressure Data for Intermediate Temperature Heat Pipe Fluids.

Merit number data are presented in Fig. 3. Water has the highest merit number by a large margin even at $600 \mathrm{~K}$, although, steeply declining, and its vapor pressure, sharply increasing with temperature. Provided the high vapor pressure issue is addressed as discussed above, water appears to be an attractive option as a heat pipe fluid in the temperature range up to about $550 \mathrm{~K}$. The merit numbers for $\mathrm{BiCl}_{3}, \mathrm{GaCl}_{3}$, and $\mathrm{GaBr}_{3}$ use a constant latent heat at the normal boiling point, since their critical temperatures are not known.

The viscosity of sulfur is too high in this temperature range to make it a candidate fluid. However, the addition of small amount of iodine $(90 \% \mathrm{~S}-10 \% \mathrm{I})$ will offset this adverse effect (Polasec and Stulc, 1976; Rosenfeld and Lindemuth, 1992). Pure Iodine is also a candidate fluid, and has been used in a heat pipe (Rosenfeld and Lindemuth, 1992). Iodine's two disadvantages are (1) low thermal conductivity (sintered metal wicks must be used in the heat pipe) and (2) corrosiveness, since it is a very reactive fluid. Lindemuth and Rosenfeld (1993) fabricated and tested an iodine heat pipe with a $304 \mathrm{SS}$ wall. The wick was two wraps of 400-mesh 304-stainless- steel screen. The pipe was operated successfully with a relatively high temperature drop, but was not life tested. 
All the halides evaluated are potentially good candidates as intermediate temperature heat pipe fluids because of their moderate vapor pressures and reasonably good values of merit numbers. It should be noted that the halides shown are the only halides for which sufficient data exist to estimate merit number; other halides might actually be better heat pipe fluids. Data of thermo-chemical compatibility with envelope and wick metals are scarce and only a small amount of life test data exist (Saaski and Tower, 1977, Anderson et al, 2004). Further tests are in progress in NASA Glenn Research Center.

From Fig. 3, two interesting halides are antimony tribromide $\left(\mathrm{Sb} \mathrm{Br}_{3}\right)$ and bismuth trichloride $\left(\mathrm{Bi}_{3}\right)$. Anderson (2005) evaluates heat pipes with these two working fluids. Bismuth trichloride is similar in behavior to sulfur $/ 10 \%$ iodine. Its vapor pressure is not high in the intermediate temperature range and its merit number is lower only to that of water at elevated temperatures. The merit number increases with temperature in the range where water's is steeply falling. As shown in Fig.4, it has a very high liquid viscosity. This is partially offset by their high surface tension, as shown in Fig. 5.

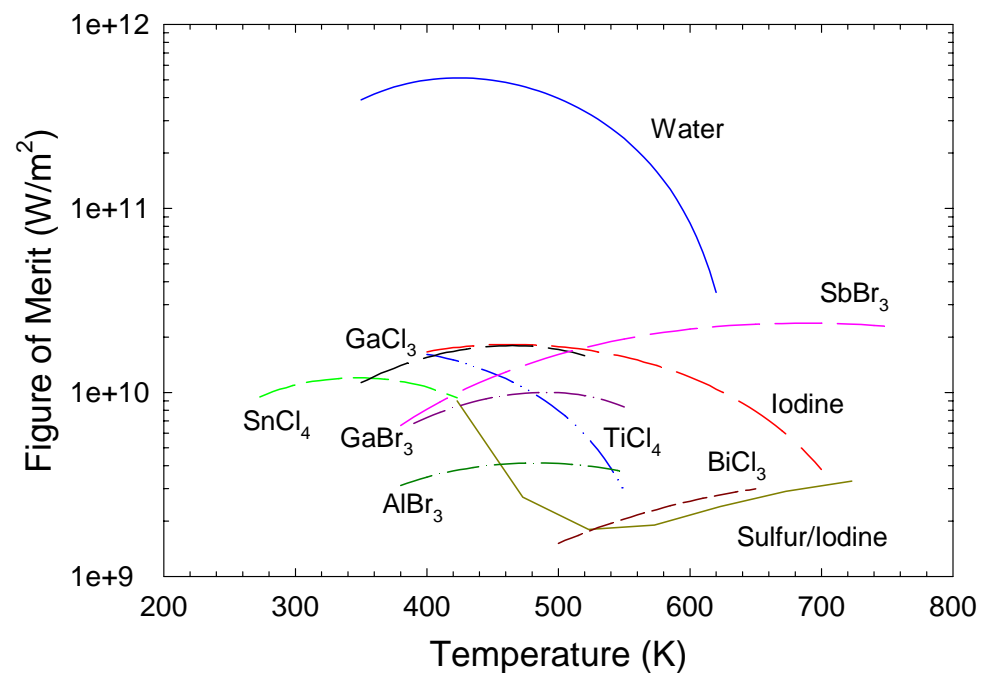

FIGURE 3. Merit Number for Various Intermediate Temperature Fluids.

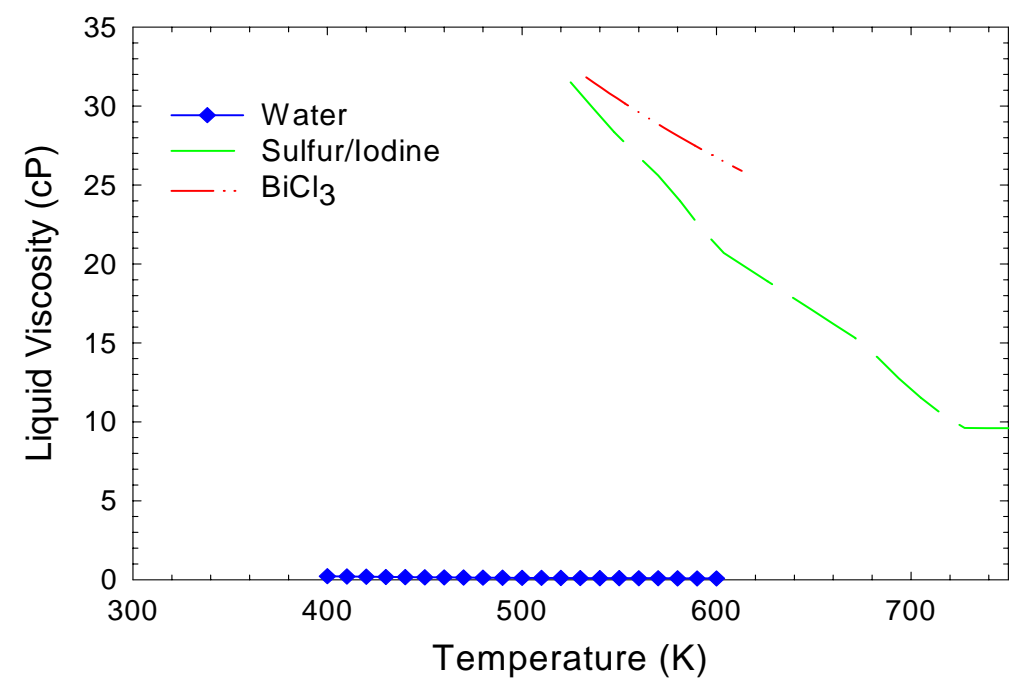

FIGURE 4. Experimental Liquid Viscosities for water, Sulfur $/ 10 \%$ iodine, and $\mathrm{BiCl}_{3}$. 


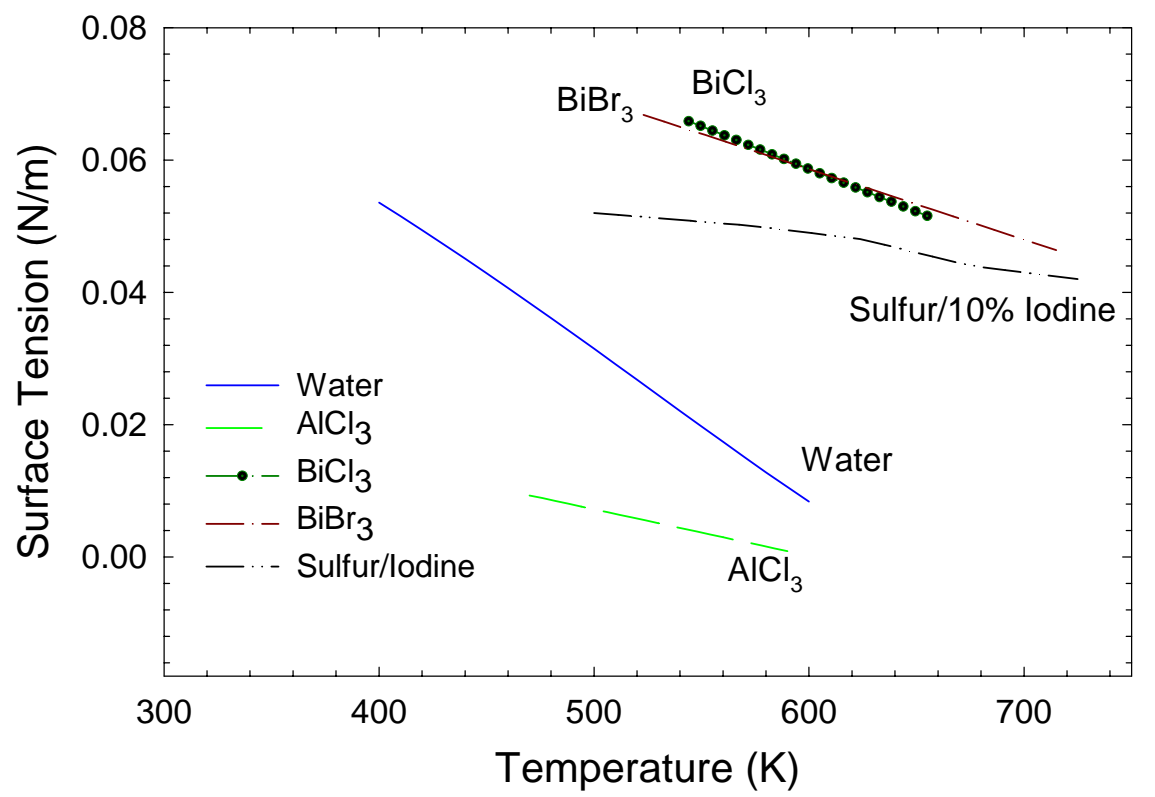

FIGURE 5. Experimental Values of Surface Tension for Water, Sulfur/10\% Iodine, and the Aluminum and Bismuth Halides.

TABLE 1. Intermediate Temperature Heat Pipe Fluids - Organic and Elemental.

\begin{tabular}{|l|c|c|c|c|c|}
\hline \multicolumn{1}{|c|}{ Fluid } & Composition & $\begin{array}{c}\text { Melting } \\
\text { Point, K }\end{array}$ & $\begin{array}{c}\text { Boiling } \\
\text { Temp., K }\end{array}$ & $\begin{array}{c}\text { Critical } \\
\text { Temp., K }\end{array}$ & $\begin{array}{c}\text { Critical Pressure, } \\
\text { MPa }\end{array}$ \\
\hline Water & $\mathrm{H}_{2} \mathrm{O}$ & 273 & 373 & 647 & 22.12 \\
\hline Dowtherm A & Diphenyl/Diphenyl Oxide & 285 & 530 & 770 & 3.135 \\
\hline Sulfur & $\mathrm{S}$ & 386 & 718 & 1314 & 20.7 \\
\hline Sulfur/10\% Iodine & $\mathrm{S} / 10 \% \mathrm{I}$ & 390 & - & - & \\
\hline Bromine & $\mathrm{Br}$ & 266 & 332 & 588 & 10.3 \\
\hline Iodine & $\mathrm{I}_{2}$ & 387 & 458 & 785 & 11.6 \\
\hline Naphthalene & $\mathrm{C}_{10} \mathrm{H}_{8}$ & 354 & 491 & 748 & 4.05 \\
\hline Phenol & $\mathrm{C}_{6} \mathrm{H}_{6} \mathrm{O}$ & 314 & 455 & 694 & 6.13 \\
\hline Toluene & $\mathrm{C}_{6} \mathrm{H}_{5} \mathrm{CH}_{3}$ & 178 & 384 & 592 & 4.1 \\
\hline Hydrazine & $\mathrm{N}_{2} \mathrm{H}_{4}$ & 275 & 387 & 653 & 14.7 \\
\hline Aniline & $\mathrm{C}_{6} \mathrm{H}_{7} \mathrm{~N}$ & 267 & 458 & 699 & 5.3 \\
\hline
\end{tabular}


TABLE 2. Candidate Fluids and Their Properties, Including Halides with Incomplete Data.

\begin{tabular}{|c|c|c|c|c|c|c|c|c|}
\hline Fluid & $\begin{array}{l}\text { Melting } \\
\text { Point, K } \\
\end{array}$ & $\begin{array}{c}\text { Boiling } \\
\text { Point, K }\end{array}$ & $\begin{array}{c}\text { Critical } \\
\text { Temp., K }\end{array}$ & $\begin{array}{c}\text { Critical } \\
\text { Press. } \\
\text { Atm. } \\
\end{array}$ & $\begin{array}{c}\text { Latent } \\
\text { Heat } \\
\text { (Boiling } \\
\text { Point) } \\
\text { kJ/kg } \\
\end{array}$ & $\begin{array}{c}\text { Liquid Density } \\
\text { kg/m } \mathbf{m}^{3}\end{array}$ & $\begin{array}{c}\text { Surface Tension, } \\
\mathbf{N} / \mathbf{m} \\
\end{array}$ & Viscosity, cPoise \\
\hline Water & 273 & 373 & 647 & 218.3 & 2257 & $832(500 \mathrm{~K})$ & $0.0315(500 \mathrm{~K})$ & $0.118(500 \mathrm{~K})$ \\
\hline Cs & 302 & 941 & 2045 & 114.7 & 531.7 & $1667(600 \mathrm{~K})$ & $0.0557(600 \mathrm{~K})$ & $0.250(600 \mathrm{~K})$ \\
\hline $\mathrm{S} / \mathrm{I}$ & 390 & $718(S)$ & $1314(\mathrm{~S})$ & $204.3(\mathrm{~S})$ & 309.3 & $1717(600 \mathrm{~K})$ & $0.0490(600 \mathrm{~K})$ & $21.0(600 \mathrm{~K})$ \\
\hline $\mathrm{I}_{2}$ & 387 & 458 & 785 & 116 & 171.4 & $3740(453 \mathrm{~K})$ & $0.031(550 \mathrm{~K}) \mathrm{e}$ & $1.27(475 \mathrm{~K})$ \\
\hline $\mathrm{AlCl}_{3}$ & 451 & $456 \mathrm{sub}$ & 620 & 26.0 & - & $1202(500 \mathrm{~K})$ & $0.0072(500 \mathrm{~K})$ & $0.244(500 \mathrm{~K})$ \\
\hline $\mathrm{AlBr}_{3}$ & 370 & 528 & 763 & 28.5 & 85.5 & $2331(500 \mathrm{~K})$ & $0.016(500 \mathrm{~K}) \mathrm{e}$ & $0.809(500 \mathrm{~K})$ \\
\hline $\mathrm{AlI}_{3}$ & 464 & 658 & 983 & - & 158.2 & $3133(500 \mathrm{~K})$ & - & $2.10(500 \mathrm{~K})$ \\
\hline $\mathrm{BCl}_{3}$ & 165.9 & 285.8 & 455 & 38.2 & 203.15 & $1340(285 \mathrm{~K})$ & - & - \\
\hline $\mathrm{BBr}_{3}$ & 227 & 364 & 581 & - & - & $2643(291 \mathrm{~K})$ & - & - \\
\hline $\mathrm{BI}_{3}$ & 323.1 & 483 & 773 & - & - & $3350(323 \mathrm{~K})$ & - & - \\
\hline $\mathrm{BiCl}_{3}$ & 503 & 714 & - & - & 229.6 & $3693(600 \mathrm{~K})$ & $0.0586(600 \mathrm{~K})$ & $19.4(600 \mathrm{~K})$ \\
\hline $\mathrm{BiBr}_{3}$ & 491 & 734 & - & - & 168 & $4477(600 \mathrm{~K})$ & $0.0586(600 \mathrm{~K})$ & - \\
\hline $\mathrm{BiI}_{3}$ & 681 & $\sim 773$ & - & - & - & $4866(600 \mathrm{~K})$ & - & - \\
\hline $\mathrm{GaCl}_{3}$ & 351 & 474 & - & - & 356.7 & $1743(500 \mathrm{~K})$ & $0.0124(500 \mathrm{~K})$ & $0.449(500 \mathrm{~K})$ \\
\hline $\mathrm{GaBr}_{3}$ & 395 & 552 & - & - & 189.4 & $2770(500 \mathrm{~K})$ & $0.0195(500 \mathrm{~K})$ & $1.027(500 \mathrm{~K})$ \\
\hline $\mathrm{GaI}_{3}$ & 485 & $618 \mathrm{sub}$ & - & - & - & $3590(500 \mathrm{~K})$ & - & - \\
\hline $\mathrm{SbCl}_{3}$ & 346 & 556 & - & - & 190.7 & $2329(500 \mathrm{~K})$ & - & $0.337(500 \mathrm{~K})$ \\
\hline $\mathrm{SbBr}_{3}$ & 370 & 553 & 1178 & 55 & 163.2 & $3193(500 \mathrm{~K})$ & $0.026(550 \mathrm{~K}) \mathrm{e}$ & $0.957(500 \mathrm{~K})$ \\
\hline $\mathrm{SbI}_{3}$ & 443 & 674 & - & - & 136.7 & $3776(600 \mathrm{~K})$ & - & - \\
\hline $\mathrm{SiCl}_{4}$ & 204.3 & 330.8 & 508.1 & 35.4 & 170.1 & $1259(400 \mathrm{~K})$ & - & - \\
\hline $\mathrm{SiBr}_{4}$ & 278.6 & 427 & 663 & - & - & $2852(298 \mathrm{~K})$ & - & - \\
\hline $\mathrm{SiI}_{4}$ & 393.7 & 560.5 & 944 & - & 93.7 & $3589(500 \mathrm{~K})$ & - & - \\
\hline $\mathrm{SnCl}_{4}$ & 240 & 388 & 592 & 37.0 & 130.1 & $1944(400 \mathrm{~K})$ & $0.0155(400 \mathrm{~K})$ & $0.360(400 \mathrm{~K})$ \\
\hline $\mathrm{SnBr}_{4}$ & 303 & 478 & - & - & 93.5 & - & - & - \\
\hline $\mathrm{SnI}_{4}$ & 418 & 638 & - & - & 80.15 & $3834(400 \mathrm{~K})$ & - & - \\
\hline $\mathrm{TiCl}_{4}$ & 243 & 409.6 & 638 & 46.0 & 190.9 & $1543(400 \mathrm{~K})$ & $0.0211(400 \mathrm{~K})$ & $0.391(400 \mathrm{~K})$ \\
\hline $\mathrm{TiBr}_{4}$ & 312 & 506 & 795.7 & - & 120.8 & $2758(400 \mathrm{~K})$ & - & - \\
\hline $\mathrm{TiI}_{4}$ & 427 & 650 & 1040 & - & 101 & $3258(500 \mathrm{~K})$ & - & - \\
\hline
\end{tabular}

Sub $=$ Sublime

$\mathrm{e}=$ estimate

\section{CONCLUSIONS}

Further evaluations are reported for potential intermediate temperature fluids in the range, 400 to $700 \mathrm{~K}$. Only limited amount of data could be obtained for halides, many of which may be suitable as heat pipe fluids. Some properties are estimated based on standard procedures. Limited data are available for chemical compatibility tests with potential envelope and wick materials. Life test data are nearly non-existent. More detailed compatibility studies are currently undertaken at NASA Glenn Research Center. 


\section{NOMENCLATURE}

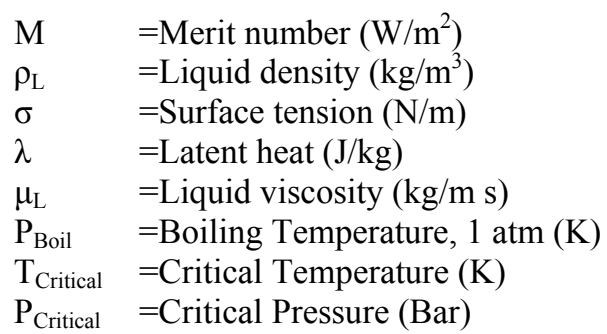

\section{REFERENCES}

Anderson, W. G., and Stern, T., "Heat Pipe Radiator Trade Study for the 300-550 K Temperature Range," STAIF 2005, Albuquerque, NM, February 13-17, 2005.

Anderson, W. G., "Evaluation of Heat Pipes in the Temperature Range of 450 to 700 K," STAIF 2005, Albuquerque, NM, February 13-17, 2005.

Anderson, W. G., Rosenfeld, J. H., Angirasa, D., and Me, Y., "Evaluation of Heat Pipe Working Fluids in the Temperature Range 450 to $700 \mathrm{~K}$," STAIF-2004, Albuquerque, NM, 2004.

Anderson, W. G., et al., "High Temperature Loop Heat Pipes," Proceedings of the 30th Annual IECEC, Vol. 1, pp. 543-548, Orlando, FL, 1995.

CRC Handbook of Chemistry and Physics, $57^{\text {th }}$ Edition, CRC Press, Cleveland, OH, 1976.

Devarakonda, A., and Olminsky, J. K., "An Evaluation of Halides and Other Substances as Potential Heat Pipe Fluids," $2^{\text {nd }}$ International Energy Conversion Engineering Conference, Providence, Rhode Island, 2004.

Janz, G. J., Thermodynamic and Transport Properties for Molten Salts: Correlation Equations for Critically Evaluated Density, Surface Tension, Electrical Conductance, and Viscosity Data, Journal of Physical and Chemical Reference Data, Volume 17, Supplement No. 2, National Bureau of Standards, 1988.

Lindemuth, J. E. and Rosenfeld, J. H., "Heat Pipe Cooling of Faraday Shields", Final Report Contract DE-F601-90-ER81058, July $9,1993$.

Meyer, C. A., McClintock, R. B., Silvestri, G. J., and Spencer, R. C., ASME Steam Tables: Thermodynamic and Transport Properties of Steam, 6th Ed., ASME Press, New York, New York, 1993.

Ohse, R. W., Editor, Handbook of Thermodynamic and Transport Properties of Alkali Metals, Blackwell Scientific Publications, Boston, MA, 1985.

Perry, R. H., and Green, D., Perry’s Chemical Engineers Handbook, Sixth Edition, McGraw Hill, New York, New York, 1984.

Polasek, F., and Stulc, P., "Heat Pipe for the Temperature Range from 200 to $600^{\circ}$ C," Proc., Second International Heat Pipe Conference, Bologna, Italy, 2, pg. 711, 1976.

Reid, R. C., Prausnitz, J. M., and Poling, B. E., The Properties of Gases and Liquids, Fourth Edition, McGraw Hill, New York, New York, 1987

Rosenfeld, J. H., and Lindemuth, J. E., "Sulfur Heat Pipes for 600 K Space Heat Rejection Systems," Final Report for NASA LERC, Contract No. NAS3-26324, 1992.

Saaski, E., and Tower, L., "Two-phase Working Fluids for the Temperature Range 100-350 ${ }^{\circ}$," American Institute of Aeronautics and Astronautics, 12th Thermophysics Conference, Albuquerque, NM., June 27-29, 1977.

Smithells Metals Reference Book, 6th Edition, E. A. Brandes, Editor, Butterworths, Boston, MA, 1983.

Stull, D. R., "Vapor Pressure of Pure Substances", Ind. Engrg. Chem., Vol. 39, 517-550, 1947. 


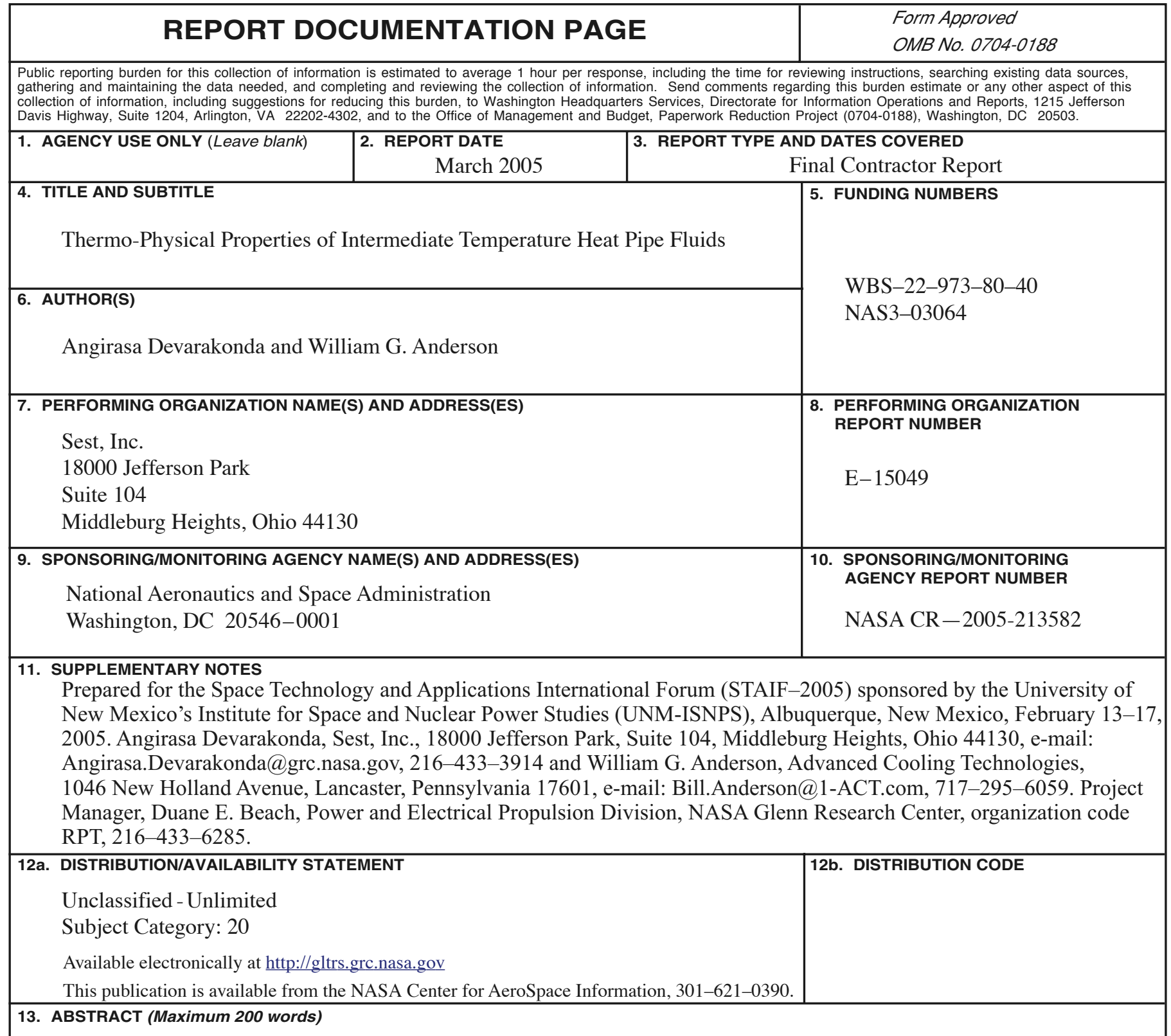

Heat pipes are among the most promising technologies for space radiator systems. The paper reports further evaluation of potential heat pipe fluids in the intermediate temperature range of 400 to $700 \mathrm{~K}$ in continuation of two recent reports. More thermo-physical property data are examined. Organic, inorganic, and elemental substances are considered. The evaluation of surface tension and other fluid properties are examined. Halides are evaluated as potential heat pipe fluids. Reliable data are not available for all fluids and further database development is necessary. Many of the fluids considered are promising candidates as heat pipe fluids. Water is promising as a heat pipe fluid up to 500 to $550 \mathrm{~K}$. Life test data for thermo-chemical compatibility are almost non-existent.

\begin{tabular}{|c|c|c|c|}
\hline \multicolumn{3}{|l|}{ 14. SUBJECT TERMS } & 15. NUMBER OF PAGES \\
\hline \multicolumn{3}{|l|}{ Heat pipes } & \begin{tabular}{|r}
14 \\
16. PRICE CODE
\end{tabular} \\
\hline $\begin{array}{l}\text { 17. SECURITY CLASSIFICATION } \\
\text { OF REPORT }\end{array}$ & $\begin{array}{l}\text { 18. SECURITY CLASSIFICATION } \\
\text { OF THIS PAGE }\end{array}$ & $\begin{array}{l}\text { 19. SECURITY CLASSIFICATION } \\
\text { OF ABSTRACT }\end{array}$ & 20. LIMITATION OF ABSTRACT \\
\hline Unclassified & Unclassified & Unclassified & \\
\hline
\end{tabular}



